\title{
A Direct DME High Temperature PEM Fuel Cell
}

Vassiliev, Anton; Jensen, Jens Oluf; Li, Qingfeng; Pan, Chao; Cleemann, Lars Nilausen; Steenberg, T.; Bjerrum, Niels

\author{
Published in: \\ E C S Transactions
}

Publication date:

2012

Link back to DTU Orbit

Citation $(A P A)$ :

Vassiliev, A., Jensen, J. O., Li, Q., Pan, C., Cleemann, L. N., Steenberg, T., \& Bjerrum, N. (2012). A Direct DME High Temperature PEM Fuel Cell. E CS Transactions, 50.

\section{General rights}

Copyright and moral rights for the publications made accessible in the public portal are retained by the authors and/or other copyright owners and it is a condition of accessing publications that users recognise and abide by the legal requirements associated with these rights.

- Users may download and print one copy of any publication from the public portal for the purpose of private study or research.

- You may not further distribute the material or use it for any profit-making activity or commercial gain

- You may freely distribute the URL identifying the publication in the public portal

If you believe that this document breaches copyright please contact us providing details, and we will remove access to the work immediately and investigate your claim 


\section{A direct DME high temperature PEM fuel cell}

A. Vassiliev ${ }^{1}$, J. O. Jensen ${ }^{1}$ *, Q. $\mathrm{Li}^{1}$, C. $\mathrm{Pan}^{1}$, L. N. Cleemann $^{1}$, T. Steenberg ${ }^{2}$, H. A. Hjuler ${ }^{2}$ and N. J. Bjerrum ${ }^{1}$.

${ }^{1}$ Department of Energy Conversion and Storage Technical University of Denmark, Kemitorvet 207, 2800 Kgs. Lyngby, Denmark

${ }^{2}$ Danish Power Systems ApS, Rådhusvej 59, DK-2920 Charlottenlund, Denmark

The paper presents a vapor fed direct dimethyl ether (DME) fuel cell based on a high temperature PEM fuel cell.

Direct methanol fuel cells are a quite well established technology today. The conversion efficiency is not as high as for hydrogen powered cells, but the energy density and ease of handling and storage of methanol offset this in several applications. DME is a comparable synthetic fuel [1] with a specific energy similar to ethanol, i.e. significantly higher than methanol. Why not convert DME directly in a PEM fuel cell like we do with methanol?

DME is a gas at ambient conditions, but when compressed to ca. 5 bar overpressure it liquefies. The vapor pressure is actually between that of propane and nbutane. This means that handling is comparable to that of liquefied petroleum gas. It is mostly non-toxic and moreover, and it has been shown that it is an excellent diesel fuel with a cetane number of 55-60. When combusted in a diesel engine it produces no soot. The reason for this is that the molecule contains no carboncarbon bonds unlike the hydrocarbons that constitute conventional diesel. DME is already common in East Asia and it may soon become an important fuel worldwide. Volvo conducts experiments with DME fuelled busses.

The absence of carbon-carbon bonds and its resemblance to methanol make it obvious to consider it for direct conversion in a PEM fuel cell, but the limited number of attempts with perfluorosulphonic acid based cells have not been very successful. Key problems are those already known from direct methanol cells (fuel crossover and slow kinetics) but of similar importance, DME is a gas at ambient conditions with limited solubility in water. When a liquid fuel-water mixture is fed to the fuel cell it may separate into two phases. This problem can be mitigated by pressurizing the system, but this consumes energy and is generally not a very attractive option for direct fuel cell systems which are meant to be simple.

The high temperature PEM fuel cell (HTPEMFC) system based on phosphoric acid doped polybenzimidazole (PBI) capable of operation at temperatures above $100^{\circ} \mathrm{C}$ has been undergoing a significant development recently [2]. It has also been used with direct methanol fuelling [3]. If a HT-PEMFC is fed with a vapor mixture of water and DME, the phase separation problem is no longer present and any desired DME-water molar ratio can be applied [4]. Moreover, crossover should be less than for methanol due to the less polar character and thus lower solubility of DME as compared with methanol.

In this study the solubility problem is discussed and quantified, single cell performance is presented and a comparison with direct methanol HT-PEMFC is made. The experimental setup is shown in Figure 1. The cell was operated a temperatures between 150 and $200^{\circ} \mathrm{C}$ with a peak power density of up to $70 \mathrm{~mW} \mathrm{~cm}$.-2.

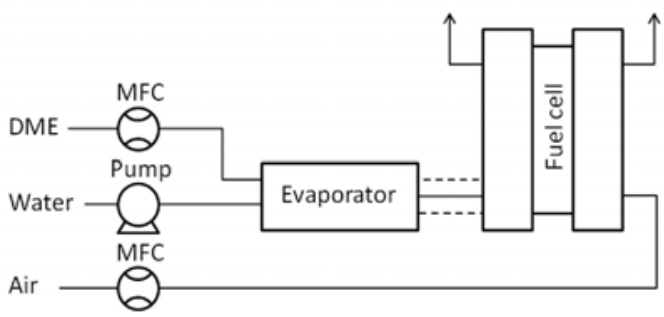

Figue 1. The experimental setup for the vapor fed direct DME fuel cell.

\section{References}

[1] T. A. Semelsberger, R. L. Borup, H. L. Greene. Journal of Power Sources, 156, 2006, 497-511

[2] Q. Li, J. O. Jensen, R. F. Savinell and N. J. Bjerrum. Progress in Polymer Science, 34, 2009, 449-477

[3] J. Lobato, P. Canizares, M. A. Rodrigo, J. J. Linares, and Ruben Lopez-Vizcaino, Energy \& Fuels, 22, 2008, 3335-3345

[4] J.O. Jensen, A. Vassiliev et al. In press, J. Power Sources. DOI: 10.1016/j.jpowsour.2012.03.039 